\title{
The net water uptake by excitable cells is a primary mechanism for pain signal generation
}

\section{Sinerik Ayrapetyan*}

Life Sciences International Postgraduate Educational Center, Yerevan, Armenia

\begin{abstract}
From the biophysical point of view pain signal can be considered as an abnormal (hyper) excitation of neuronal and muscle membranes, which is transmitted into central nervous system (CNS) and generates pain sensation. Since pain can be generated by different phenomena, starting from mechanical damage to the breakdown of different metabolic pathways, there must be a common cellular mechanism through which various physical, chemical and metabolic factors generate abnormal excitation of cell membrane. It is known that pain sensation can be changed upon the effect of extremely weak chemical and physical signals, having intensity even less than thermal threshold and non-linear dose-dependent character. Therefore, such a cellular target must have a quantum-mechanical nature.
\end{abstract}

From the biophysical point of view pain signal can be considered as an abnormal (hyper) excitation of neuronal and muscle membranes, which is transmitted into central nervous system (CNS) and generates pain sensation. Hence, the bioequivalence of the water by the cells in the body determines the phenomenon. Since pain can be generated by different phenomena, starting from mechanical damage to the breakdown of different metabolic pathways, there must be a common cellular mechanism through which various physical, chemical and metabolic factors generate abnormal excitation of cell membrane. It is known that pain sensation can be changed upon the effect of extremely weak chemical and physical signals, having intensity even less than thermal threshold and non-linear dose-dependent character. Therefore, such a cellular target must have a quantum-mechanical nature. Previously we have suggested that cell hydration is a fundamental cell parameter which has quantum-mechanical sensitivity and determines cell functional activity, including membrane excitability [1-3]. The cell hydration-induced control of its functional activity is realized by surface dependent-changes of the number of functionally active proteins (enzymes, receptors and channels) in the membrane and hydrationinduced regulation of intracellular macromolecules' activity through folding-unfolding mechanism [4-7]. Moreover, it has been shown that the metabolic control of cell membrane excitability has a crucial role in trans-membrane water fluxes-induced activation and inactivation of ionic channels. The water fluxes have activation effect on ionic currents having the same directions and inactivation effect on the currents with opposite directions $[6,8]$. As intracellular osmotic pressure exceeds the extracellular one, water efflux from the cells has a metabolic nature and it has been suggested that the metabolic generation of water efflux from the cell is a pathway through which the low permeability of membrane for inward $\mathrm{Na}^{+}$and $\mathrm{Ca}^{2+}$ currents is controlled $[6,9]$. Therefore, the impairment of metabolically generated water efflux from the cells, bringing to the activation of net water influx, which in its turn leads to membrane permeability for $\mathrm{Na}^{+}$and $\mathrm{Ca}^{2+}$, is a common consequence of any pathology. On the basis of these data previously we have suggested that pain sensation is a result of overhydration-induced hyper excitation of neuronal and muscle membranes [10]. According to this hypothesis the activation of water efflux from the neuronal and muscle cells could have pain-relieving effect. Therefore, the evaluation of the nature of the metabolic mechanism responsible for generation of water efflux from the cells seems extremely important from the point of effective pain therapy.

It is known that water efflux can be generated by electrogenic ion transporting process pushing out more osmotic active particles from the cells than up taking as well as by releasing water molecules in cytoplasm during intracellular oxidative process. In these two aspects the $\mathrm{Na}^{+} / \mathrm{K}^{+}$pump has a crucial role in metabolic regulation of cell volume: from one side $\mathrm{Na}^{+} / \mathrm{K}^{+}$pump functioning in stoichiometry of $3 \mathrm{Na}^{+}: 2 \mathrm{~K}^{+}$pushes out more osmotic particles that uptakes, from the other side $\mathrm{Na}^{+} / \mathrm{K}^{+}$pump, being the highest ATP utilizing machine, stimulates the intracellular metabolism leading to water molecule release in cytoplasm $[11,12]$.

It is known that $\mathrm{Na}^{+/} \mathrm{K}^{+}$-ATPase in nerve and muscle membranes has three catalytic isoforms having different affinities to ouabain. The isoforms with low affinity to ouabain (al-agonist $>10-7 \mathrm{M}$ ) have $\mathrm{Na}^{+} /$ $\mathrm{K}^{+}$-pump function, while the middle (a2-agonist $\mathrm{nM}$ ) and the highest (a3-agonist $\mathrm{pM}$ ) affinity isoforms have only intracellular signaling function regulating $\left[\mathrm{Ca}^{2+}\right]$ i through $\mathrm{Na}^{+} / \mathrm{Ca}^{2+}$ exchange localized in cell membrane $[13,14]$. Traditionally, the correlation between $\mathrm{Na}^{+} / \mathrm{K}^{+}$ pump and $\mathrm{Na}^{+} / \mathrm{Ca}^{2+}$ exchange is explained by pump-induced changes of the $\mathrm{Na}^{+}$gradient on the membrane $[13,15,16]$. However, by our earlier work it has been shown that ouabain at $\mathrm{nM}$ and $\mathrm{pM}$ concentrations can have activation effects on $\mathrm{Na}^{+} / \mathrm{Ca}^{2+}$ exchange in reverse (R) and forward (F) modes, respectively without having direct effect on $\mathrm{Na}^{+} /$ $\mathrm{K}^{+}$pump activity $[4,17]$. It has been shown that the activation of $\mathrm{R} \mathrm{Na}^{+} /$ $\mathrm{Ca}^{2+}$ exchange is accompanied by the increase of intracellular cAMP contents, while the activation of $\mathrm{F} \mathrm{Na}{ }^{+} / \mathrm{Ca}^{2+}$ exchange by the increase of intracellular cGMP contents $[17,18]$. The role of cyclic nucleotides in controlling $\left[\mathrm{Ca}^{2+}\right] \mathrm{i}$ and in regulation of $\mathrm{Na}^{+} / \mathrm{Ca}^{2+}$ exchange was thoroughly described in the excellent review by Brini and Carafoli [19].

By our study it has also been shown that both $\mathrm{R}$ and $\mathrm{F}$ modes of $\mathrm{Na}^{+} /$ $\mathrm{Ca}^{2+}$ exchange serve as common sensors not only for low concentrations of ouabain but also for other weak chemical and physical signals such

*Corresponding author: Sinerik Ayrapetyan, UNESCO Chair in Life Sciences, Life Sciences International Postgraduate Educational Center, Acharyan 31, Yerevan 0040, Armenia, Tel: +374 10 624170/612461; Fax: +37410 624170; E-mail: info@biophys.am

Received May 10, 2018; Accepted May 15, 2018; Published May 20, 2018

Citation: Ayrapetyan S (2018) The net water uptake by excitable cells is a primary mechanism for pain signal generation. J Bioequiv Availab 10: e86. doi: 10.4172/0975-0851.1000e86

Copyright: ( 2018 Ayrapetyan S. This is an open-access article distributed under the terms of the Creative Commons Attribution License, which permits unrestricted use, distribution, and reproduction in any medium, provided the original author and source are credited. 
Citation: Ayrapetyan S (2018) The net water uptake by excitable cells is a primary mechanism for pain signal generation. J Bioequiv Availab 10 : e86. doi: 10.4172/0975-0851.1000e86

as synaptical transmitters, their agonists and antagonists as well as for ionizing and non-ionizing radiation [20-25]. Meanwhile, cGMPdependent $\mathrm{F} \mathrm{Na}^{+} / \mathrm{Ca}^{2+}$ exchange is more sensitive to aging and different factors than cAMP-dependent $\mathrm{R} \mathrm{Na}^{+} / \mathrm{Ca}^{2+}$ exchange [26-28]. It has been shown that the increase of lipid fluidity $(\sim 40 \%)$ by the involvement of non-metabolized decanoic fatty acid in neuronal membrane leads to cell swelling, which is accompanied by the increase of intracellular cGMP contents without changing intracellular cAMP level $[3,29,30]$. These data allow us to consider that the water uptake-induced elevation of cGMP is a primary metabolic response to water uptake. The study of the feedback effect of cGMP-dependent $\mathrm{Na}^{+} / \mathrm{Ca}^{2+}$ exchange on cell hydration has shown that though $\mathrm{Na}^{+} / \mathrm{Ca}^{2+}$ exchange functions in stoichiometry of $3 \mathrm{Na}^{+}: 1 \mathrm{Ca}^{2+}$, the $\mathrm{F} \mathrm{Na}^{+} / \mathrm{Ca}^{2+}$ exchange has dehydration effect on brain tissue in young (healthy) animals, while in older (nonhealthy) animals it has hydration effect. More detailed investigation of the nature of $\mathrm{F} \mathrm{Na}^{+/} \mathrm{Ca}^{2+}$ exchange on brain tissue dehydration has shown that in healthy animals the cGMP-dependent $\mathrm{F} \mathrm{Na}^{+} / \mathrm{Ca}^{2+}$ induced cell dehydration is due to activation of $\mathrm{Na}^{+} / \mathrm{K}^{+}$pump in result of $\left[\mathrm{Ca}^{2+}\right]$ i decrease $[15,18,27]$. Thus, $\mathrm{F} \mathrm{Na}^{+} / \mathrm{Ca}^{2+}$ exchange activation has pain-relieving effect as on one hand it leads to inhibition of membrane excitability by activation of $\mathrm{Na}^{+} / \mathrm{K}^{+}$pump through generation of water efflux from the cells and by membrane hyperpolarization, on the other hand it depresses synaptical signal transmission by decreasing $\left[\mathrm{Ca}^{2+}\right] \mathrm{i}$ [6,31-33]. In case of high $\left[\mathrm{Ca}^{2+}\right] \mathrm{i}$ (cell pathology) when the power of $\mathrm{F}$ $\mathrm{Na}^{+} / \mathrm{Ca}^{2+}$ exchange is not enough to activate $\mathrm{Na}^{+} / \mathrm{K}^{+}$pump, it leads to activation of water influx-induced generation of abnormal membrane discharge which stimulates high $\left[\mathrm{Ca}^{2+}\right]$ i-induced activation of synaptical activity into CNS and generates pain sensation. Therefore, it is suggested that the inward water fluxes through the membrane serve as cellular primary mechanism for generation of pain signals.

This suggestion can be supported by the data on pain-relieving effect of hypertonic solution and the effects of the factors activating cGMP-dependent $\mathrm{Na}^{+} / \mathrm{Ca}^{2+}$ exchange such as static magnetic field, NO donors (SNAP), mechanical vibration with infrasound frequency [22,25,34-36].

\section{References}

1. Ayrapetyan $S$ (2006) Cell aqua medium as a preliminary target for the effect of electromagnetic fields. In: Bioelectromagnetics: Current Concepts 31-63.

2. Ayrapetyan SN (2015) The role of cell hydration in realization of biological effects of non-ionizing radiation (NIR). Electromagn Biol Med 34: 197-210.

3. Ayrapetyan S (2018) Water molecules as quantum mechanical sensors and primary messengers for non-lonizing radiation effects on cells. In: lonizing Radiation: Advances in Research and Applications, T. Reeve, Nova Science Publishers, USA, 191-220.

4. Ayrapetyan SN, Suleymanyan MA, Saghyan AA, Dadalyan SS (1984) Autoregulation of electrogenic sodium pump. Cell Mol Neurobiol 4: 367-383.

5. Ayrapetyan SN, Arvanov VL, Maginyan SN, Azatyan KV (1985) Further study of the correlation between Na-Pump activity and membrane chemosensitivity. Cell Molec Neurobiol 5: 231-243.

6. Ayrapetyan SN, Rychkov GY, Suleymanyan MA (1988) Effects of water flow on transmembrane ionic currents in neurons of Helix Pomatia and in squid giant axons. Comp Biochem Physiol 89A: 179-186.

7. Parsegian VA, Rand RP, Rau DC (2000) Osmotic stress, crowding, preferential hydration, and binding: A comparison of perspectives. Proc Nat Sci USA 97: 3987-3992.

8. Suleymanian MA, Ayrapetyan VY, Arakelyan VB, Ayrapetyan VY (1993) The effect of osmotic gradient on the outward potassium current in dialyzed neurons of Helix Pomatia. Cell Mol Neurobiol 13: 183-190.

9. Rychkov GY, Suleymanyan MA, Ayrapetyan SN (1989) Dependence of water flow effect on the ionic currents of dialyzed neuron of somatic membrane fluidity. Biol Membr 6: 733-739.
10. Ayrapetyan SN (1998) The application of the theory of metabolic regulation to pain. Pain mechanisms and management, IOS press, Netherlands, 3-14.

11. Ayrapetyan SN, Sulejmanian MA (1979) On the pump-induced cell volume changes. Comp Biochem. Physiol part A Comp Pharmacol 64: 571-575.

12. Carpenter DO, Fejtl M, Ayrapetyan SN, Szarowski DH, Turner JN (1992) Dynamic changes in neuronal volume resulting from osmotic and sodium transport manipulations. Acta Biologica Hungarica 43: 39-48.

13. Blaustein MP, Lederer WJ (1999) $\mathrm{Na}^{+} / \mathrm{Ca}_{2}{ }^{+}$Exchange, Its Physiological Implications. Physiol Rev 79: 763-854.

14. Wu J, Akkuratov EE, Bai Y, Gaskill CM, Askari A, et al. (2013) Cell signaling associated with $\mathrm{Na}^{+} / \mathrm{K}^{+}$-ATPase: activation of phosphatidylinositide 3-kinase IA Akt by ouabain is independent of Src. Biochemistry 52: 9059-9067.

15. Baker PF, Blaustein MP, Hodgkin AL, Steinhardt SA (1969) The influence of calcium on sodium efflux in squid axons. J Physiol 200: 431-458.

16. Blaustein MP, Zhang J, Chen L, Song H, Raina H (2009) The pump, the exchanger, and endogenous ouabain: signaling mechanisms that link salt retention to hypertension. Hypertension 53: 291-298.

17. Sagian AA, Ayrapetyan SN, Carpenter DO (1996) Low concentrations of ouabain stimulate Na:Ca Exchange in neurons. Cell Mol Neurobiol 16: 489498.

18. Ayrapetyan S (2012) Cell hydration as a universal marker for detection of environmental pollution. Environmentalist J 32: 210-221.

19. Brini M, Carafoli E (2009) Calcium pumps in health and disease. Physiol Rev 89: $1341-1378$

20. Dadalyan SS, Kiss T, Azatian KV, Ayrapetyan SN, Salanki J (1988) The effect of low concentration of GABA on the ACh sensitivity of snail neurons. Neurobiology of invertebrates, Budapest, 643-653.

21. Ayrapetyan SN, Carpenter DO (1991) Very low concentrations of Acetylcholine and GABA modulate transmitter responses. Neuroreport 2: 563-565.

22. Azatian KV, Ayrapetyan SN, Carpenter DO (1997) Metabotropic GABA receptors regulate Acetylcholine responses on snail neurons. Gen Pharmacol 29: $67-72$.

23. Dvoretsky Al, Ayrapetyan SN, Shainskaya AM (2012) High-affinity ouabain receptors: primary membrane sensors for ionizing radiation. The Environmentalist 32: 242-248.

24. Ayrapetyan S, Baghdasaryan N, Mikayelyan Y, Barseghyan S, Martirosyan V (2015) 13 Cell Hydration as a Marker for Nonionizing Radiation. Electromagnetic Fields in Biology and Medicine, pp: 193-215.

25. Musheghyan G, Minasyan A, Arajyan G, Ayrapetyan S (2017) 4Hz mechanical vibration relieves pain through $\mathrm{Na}^{+} / \mathrm{K}^{+} A T P$-ase $\alpha 3$ isoform-dependent brain tissue dehydration. Inter J Basic and Applied Sci 6: 29-35.

26. Azatyan KV, Karapetyan IC, Ayrapetyan SN (1994) Effect of Acetylcholine of low doses on 45Ca influx into the Helix Pomatia neurons. Biol Mem Harwood Academic Publishers GmbH 7: 301-304.

27. Ayrapetyan S, Heqimyan A, Nikoghosyan A (2012) Age-dependent brain tissue hydration, $\mathrm{Ca}$ Exchange and their dose-dependent ouabain sensitivity. $J$ Bioequiv Availab 4: 060-068.

28. Heqimyan A, Narinyan L, Nikoghosyan A, Ayrapetyan S (2015) Age-dependent magnetic sensitivity of brain and heart muscles. In: Electromagnetic Fields in Biology and Medicine, CRC Press, USA, pp: 217-230.

29. Takenaka T, Horie H, Kawasaki Y (1983) Effect of fatty acids on the membrane fluidity of cultured chick dorsal root ganglion measured by fluorescence photo bleaching recovery. J Neurobiol 14: 457-461.

30. Takenaka T, Suleymanyan MA, Ayrapetyan SN (1990) The effects of shortchain fatty acids on membrane electrical properties of snail neurons. In: Metabolic regulation of membrane function. Armenian Academy of Sciences Publishers, Yerevan, pp: 154-166.

31. Kojima M, Ayrapetyan S, Koketsu K (1984) On the membrane potentia independent mechanism of sodium pump-induced inhibition of spontaneous electrical activity of Japanese land snail neurons. Comp Biochem Physio 77(A): 577-583.

32. Carpenter DO, Alving BO (1968) A contribution of electrogenic $\mathrm{Na}+$ pump to membrane potential in Aplysia neurons. J Gen Physiol 52: 1-21 
Citation: Ayrapetyan S (2018) The net water uptake by excitable cells is a primary mechanism for pain signal generation. J Bioequiv Availab 10: e86. doi: 10.4172/0975-0851.1000e86

33. Ayrapetyan SN (1969) Mechanism of regulation of spontaneous activity of snail giant neurons. Biofizika 14: 866-872.

34. Ayrapetyan SN, Grigorian CV, Avanesian AS (1994) Magnetic fields alter electrical properties of solutions and their physiological effects. Bioelectromagnetics 15: 133-142.
35. Mundell WC (2013) Static magnet therapy for pain relief: A critical review. OA Alternative Medicine 1: 19

36. Ayrapetyan G, Papanyan A, Hayrapetyan H, Ayrapetyan S (2005) Metabolic pathway of magnetized fluid-induced relaxation effects on heart muscle. Bioelectromagnetics 26: 624-630. 